\title{
MIND MAPPING STRATEGY: IS IT EFFECTIVE OR NOT TO IMPROVE THE STUDENTS' ABILITY IN WRITING TOURISM BROCHURES?
}

\author{
Albert Efendi Pohan \\ English Education Department \\ University of Riau Kepulauan \\ guruindonesia31@gmail.com
}

\begin{abstract}
The objective of this study is to find out whether Mind Mapping is effective or not in improving students' ability in writing tourism brochures at SMA 20 Batam. This study is limited on writing tourism brochure for tenth grade students at SMA Negeri 20 Batam in Academic year 2017/2018. The study was designed by the writer by using true experimental design (pre-test and post-test control group). The population of the study were tenth grade students of SMA Negeri 20 Batam academic year 2017/2018. There were eight classes of tenth grade students with the total number 300 students. The samples of this study were two classes which consist of 30 students in experiment class and 30 students in control class. The instrument of this study was written test. The data analysis was used Independent Samples Test on IBM SPSS statistics 20 to perform T-test. The result showed that the Sig.(2tailed) of students' pre-test and post-test in experimental was 0.401 and standard significance level was 0.05. By comparing the Sig.(2-tailed) and standard significance level, it was known that Sig.(2-tailed) was bigger than standard significance level

$(0.401>0.05)$. It means there was no significant difference in writing tourism brochure before and after taught by using Mind Mapping in experimental class. Therefore, the alternative hypothesis $\left(H_{a}\right)$ was rejected and the null hypothesis $\left(H_{o}\right)$ was accepted. The conclusion of Mind Mapping was not given significant effect in improving students' ability in writing tourism brochure.
\end{abstract}

Keywords: Writing, improving, mind mapping 


\section{INTRODUCTION}

For the students, to have English skills become their liability in their life. There are four skills in English language to make students truly proficient. One of the four skills in English is writing. Writing is a combination of process and product. The process refers to the act of gathering ideas and working with them until they are presented in a manner that is polished comprehensible to readers. In order to write well in English, students should understand the basic of the language and the basic of writing skills properly. With the basic of language and the basic of writing and also have valid purpose, it is easy for the students to write. Furthermore, according to Hyland (2004), the ability to communicate ideas and information effectively through the global digital network is crucially dependent on good writing skills. Good writing skills allow students to communicate their message with clarity and ease to a far larger audience than through face-to-face or telephone conversations.

According to Brown (2001: 241-246) there are three method to scoring in students writing. One of three methods to assess students writing is analytic scoring based on organization, content, grammar, punctuation, spelling, mechanic, and vocabulary. Wiseman (In Iranian Journal of Language Testing March 2012: 60) state, “ ... analytic scoring methods, in which raters make judgment about nominated features or writing skills, involve the separation of the various features of a composition into components for scoring purposes".

There are many types of written language. According to Brown (2001: 302-3) there are at least 25 types of written language including brochure. Brochure is a part of collateral advertising. In collateral advertising, usually it made by written and some can be in printed form. There are two major types of brochures; sales brochure and informational brochure. Sales brochure usually used to sell a company's products and services and informational brochures used to educate readers by giving some information. 
Before students start to make a brochure, they need some method of learning in gathering ideas after knowing the basic of the language and the basic of writing skills. Here, the writer chooses Mind Mapping method in order to make students easier in gathering ideas. According to Buzan (2005: 1), Mind Mapping is a very powerful tool for brainstorming, creative thinking, problem solving, organizing of ideas and of course, note taking. By using Mind Mapping, students can collect, create, manage, and exchange information. It is tart from the topic in the center and connected ideas in radial pattern. Because Mind Mapping contains visual elements, students can quickly and easily remember understand. Students can apply Mind Mapping in many situations such as manuscript for studying, presentation, project management, knowledge management, and also taking note from texts book.

\section{METHODOLOGY}

The study designed was true experimental design. According to Festinger (In Pandey, 2015: 90) "The essence an experiment may be described as observing the effect on a dependent variables of the manipulation of an independent variables". It means in experimental study may be defined as the study of the relationship among variables those manipulated and those measured. To collect the data in experimental study, two groups were used. They were experimental group and control group. The experimental group was the group that received the treatment by using Mind Mapping.

This study was conducted at first year students of SMA Negeri 20 Batam in academic year 2017/2018 and held on August until September 2017. The population of the study was 2017/2018 first year students of SMA Negeri 20 Batam. There were eight classes of the first year students with the total number 300 students. The samples of this research were two classes of first year students of SMA Negeri 20 Batam in the academic year 2017/2018. The samples were experimental and control class. In experiment class there was 30 students and control class there was 30 students, the amounts of students were 60 students. 
For the instrument of the study, the writer gave the written test to the students. So, the students were asked to write a tourism brochure as "One Day Batam City Tour". The writer gave time for students 45 minutes to write the brochures.

\section{RESULT}

Testing Instruments

Written Test

a. Validity

The instrument of this study had a content validity because of the design from the syllabus of the students in SMA 20 Batam in academic year 2017/2018.

b. Normality Test

Normality test used to analyze the data distribution normal or not. The writer used Kolmogorov Smirnov test in SPSS statistics 20 to perform normality test.

Table 1

Normality of Pre-Test in Control and Experimental Group

\begin{tabular}{|ll|r|r|}
\hline \multicolumn{4}{|c|}{ One-Sample Kolmogorov-Smirnov Test } \\
\hline $\mathrm{N}$ & & Control Group & Experimental Group \\
& & 30 & 30 \\
Normal Parameters ${ }^{\mathrm{a}, \mathrm{b}}$ & Mean & 58,70 & 59,30 \\
& Std. Deviation & 12,032 & 11,142 \\
& Absolute &, 108 &, 162 \\
& Positive &, 107 &, 092 \\
Most Extreme Differences & Negative &,- 108 &,- 162 \\
& &, 592 &, 890 \\
Kolmogorov-Smirnov Z & &, 875 &, 407 \\
\hline
\end{tabular}

a. Test distribution is Normal.

b. Calculated from data.

The table above describe that the data of both groups was normal. It was because the score of Asymp. Sig. (2-tailed) on control group higher than 0.05. It was $0.875>0.05$ while in experimental group, the score of Asymp. Sig.(2tailed) was $0.407>0.05$. 
Table 2

Normality of Post-Test in Control and Experimental Group One-Sample Kolmogorov-Smirnov Test

\begin{tabular}{|ll|r|r|}
\hline & & Control Group & Experimental Group \\
\hline $\mathrm{N}$ & & 30 & 30 \\
\multirow{2}{*}{ Normal Parameters } & Mean & 65,47 & 61,77 \\
& Std. Deviation & 8,085 & 11,428 \\
& Absolute &, 131 &, 160 \\
Most Extreme Differences & Positive &, 131 &, 160 \\
& Negative &,- 067 &,- 094 \\
Kolmogorov-Smirnov Z & &, 718 &, 875 \\
Asymp. Sig. (2-tailed) & &, 682 &, 428 \\
\hline
\end{tabular}

a. Test distribution is Normal.

b. Calculated from data.

\section{Normality of Post-Test in Control and Experimental Group}

From the table of normality of post-test above, it could be describe that the data of control group and experimental group were normal. In control group, the Asymp. Sig.(2-tailed) was $0.682>0.05$ while in experimental group was $0.428>0.05$.

c. Homogeneity Test

If F-count $<$ F-table, it showed that the class had homogeneity and if F-count $>$ F-table, it showed that the class had not homogeneity. It is tested by using variance test (F test), (Sugiyono, 2013:140).

The formula is follow:

$$
F=\frac{\text { Largest Variance }}{\text { Smallest Variance }}
$$


Table 3

The Summary of Homogeneity Testing

\begin{tabular}{|c|c|c|c|}
\hline Variable & $F_{\text {count }}$ & $\mathbf{F}_{\text {table }}$ & Conclusion \\
\hline $\begin{array}{l}\text { Writing Tourism Brochure in } \\
\text { Pre Test }\end{array}$ & 1.61 & 4.01 & $\begin{array}{l}\mathrm{F}_{\text {count }}<\mathrm{F}_{\text {table }} \\
\text { Homogeneous }\end{array}$ \\
\hline $\begin{array}{l}\text { Writing Tourism Brochure in } \\
\text { Post Test }\end{array}$ & 1.99 & 4.01 & $\begin{array}{l}\mathrm{F}_{\text {count }}<\mathrm{F}_{\text {table }} \\
\text { Homogeneous }\end{array}$ \\
\hline
\end{tabular}

Based on the table of summary the homogeneity testing above, the conclusion that $\mathrm{F}_{\text {count }} 1.07$ in pre-test and $\mathrm{F}_{\text {count }} 1.41$ in post-test for writing tourism brochure in control and experimental group were lower than $F_{\text {table }}$ 4.01. It means that both of the variances or classes were homogeneous.

d. Hypothesis Testing

The outcome of the pre-test and post-test on both groups was analyzed by applying the t-test. The writer used Independent t-test on SPSS statistics 20 to perform t-test.

Table 4

Independent Test in Control Group (Pre and Post-Test) 


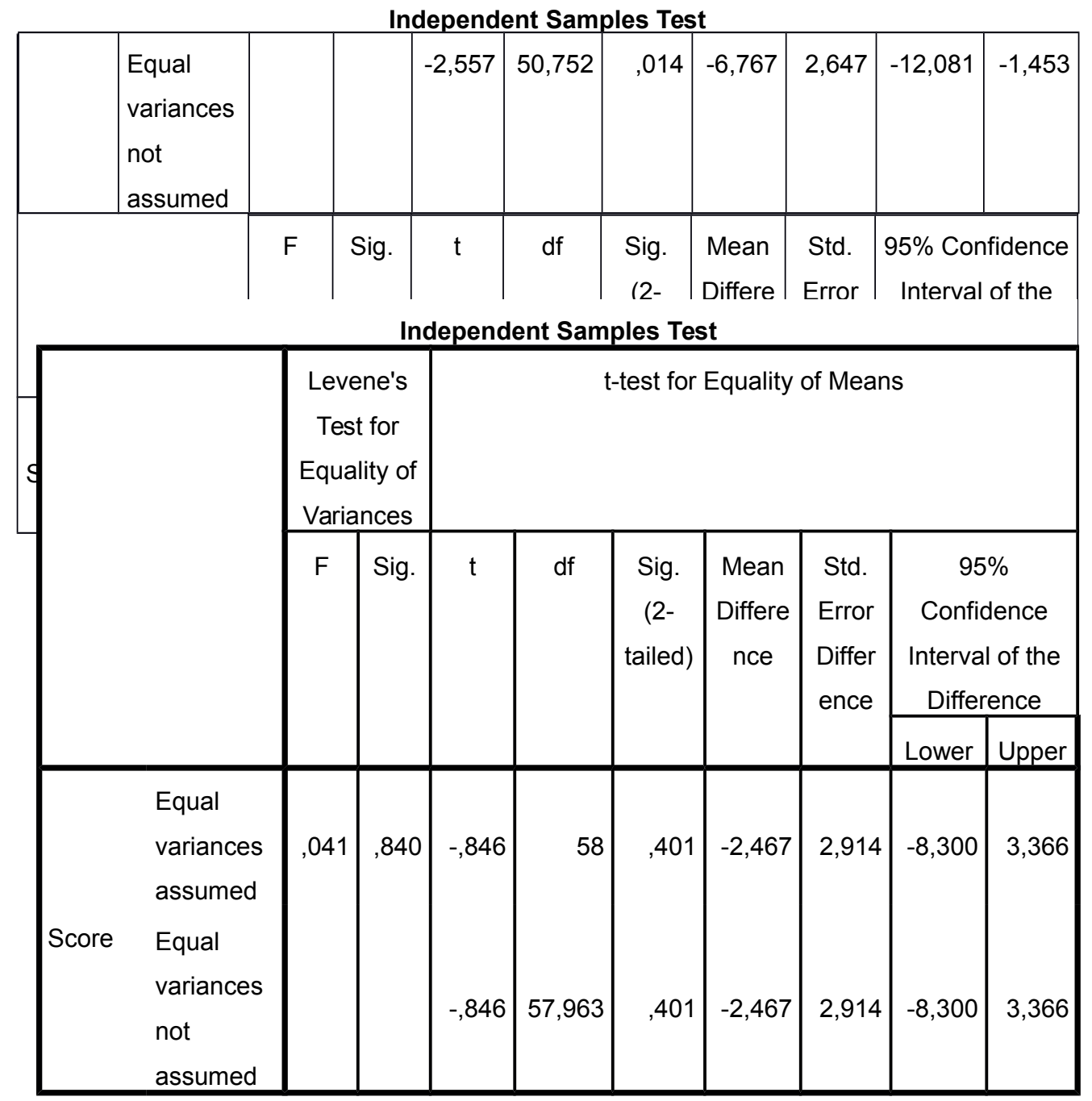

The table above shows that $t_{\text {observe }}$ was -2.557 or 2.560 (in absolute) compared with $t_{\text {table }}(2.002)$ with df n-2 $(60-2=58)$ in significance $5 \%$. It means that $t_{\text {observe }}$ was higher than $t_{\text {table }}(2.560>2.002)$ and accepted $H_{\mathrm{a}}$. The Sig.(2tailed) or $p$-value from the table above was $0.013<0.05$. It means there was significant difference between pre-test and post-test in control group taught by using discussion method.

Table 5

Independent Test of Experimental Group (Pre and Post-Test) 
To find the hypothesis, from the table of independent test of pre-test and post-test above, it shows there was no significant difference before and after taught by using Mind Mapping in experimental group. Because the Sig.(2-tailed) or $p$-value based on the table above was 0.401 higher than probability $0.05(0.401>0.05)$. Therefore, $H_{\mathrm{a}}$ was rejected and $H_{\mathrm{o}}$ was accepted; or there was no significance effect of Mind Mapping in improving students' ability in writing tourism brochures.

\section{DISCUSSION}

Based on data analysis that has been explained before, the use of Mind Mapping did not give significant effect in improving students' ability in writing tourism brochure. Based on normality and homogeneity test the data in both control and experimental was normal. But in fact, based on independent samples test, there was no significant difference before and after taught by using Mind Mapping in experimental group. Meanwhile in control group, there was significant difference before and after taught by using discussion method.

In this study, it was found that the learning material about writing tourism brochure in both control and experimental group are still in progress. The students also lack of vocabulary related to tourism. Furthermore, Mind Mapping conatins visual elements so that students in experimental group can quickly and easily memories and understand. Nevertheless, mind mapping has disadvantages too. Based on the observation did by the writer in post-test of experimental group, this strategy was not suitable for use during exam or such condition. The Mind Mapping has been considered somewhat time consuming for the students in experimental group.

Based on the result of independent test of post-test in both group by using SPSS statistics 20, the Sig.(2-tailed) or $p$-value was $0.401>0.05$. Therefore, Therefore, $H_{\mathrm{a}}$ was rejected and $H_{\mathrm{o}}$ was accepted. It was concluded that Mind Mapping did not give significant effect in improving students' ability in writing tourism brochure at SMA Negeri 20 Batam. 
Sig.(2-tailed) or $p$-value based on the table above was 0.401 higher than probability $0.05(0.401>0.05)$. Therefore, $H_{\mathrm{a}}$ was rejected and $H_{\mathrm{o}}$ was accepted; or there was no significance effect of Mind Mapping in improving students' ability in writing tourism brochures.

\section{REFERENCES}

Brown, Douglas H. 2001. Teaching by Principles: An Interactive Approach to Language Pedagogy. San Fransisco, CA: Longman.

Brown, Douglas H. 2004. Language Assessment: Principle and Classroom Practice. San Fransisco, CA: Longman.

Brown, Kristine. and Susan Hood. 1993. Writing Matters: Writing Skills and Strategies for Students of English. New York: Cambridge University Press

Hyland, Ken. 2004. Second Language Writing. New York: Cambridge University Press.

Kothari, C.R. 2004. Research Methodology: Methods and Techniques Second Revised Edition. New Delhi: New Age International Publisher.

Krasnic, Toni. 2011. How to Study With Mind Maps. Concise Books Publishing.

Maxom, Michelle. 2009. Teaching English as A Foreign Language for Dummies. Chichester: John Wiley \& Sons, Ltd.

Nurlaila, Alma Prima. 2013. The Use of Mind Mapping Technique in Writing Descriptive Text (Journal). Indonesia University of Education.

Pandey, Prabhat. 2015. Research Methodology: Tools and Techniques. Romania: Bridge Center.

Sugiyono. (2013). Statistika untuk penelitian. Bandung : Alfabeta

Wiseman, Cynthia S. A Comparison of the Performance of Analytic vs. Holistic Scoring Rubrics to Assess L2 Writing (Journal). Iranian Journal of Language Testing. 